\title{
P-T conditions of Pan-African orogeny in southeastern Nigeria
}

\author{
Bassey E. Ephraim \\ Department of Geology, Niger Delta University, \\ Wilberforce Island, Bayelsa State, Nigeria
}

\author{
Barth N. Ekwueme \\ Department of Geology \\ University of Calabar, Calabar, Nigeria
}

\author{
Monir Modjarrad \\ Department of Geology, \\ University of Urmia, Urmia, Iran \\ Department of Geology, University of Tabriz, \\ Tabriz, Iran
}

\begin{abstract}
Different rock types from the area northeast of Obudu, southeastern Nigeria were investigated in order to place constraints on their metamorphic conditions. Detailed petrographic studies indicate four main rock groups in the studied area, namely migmatitic gneiss, migmatitic schist, granite gneiss and a minor amount of amphibolite, metagabbro and dolerite. The chemistry of minerals in these rocks is used to estimate metamorphic pressure and temperature (P-T) using appropriate geothermometers and geobarometers. The estimated temperature for migmatitic gneiss of the area is $\sim 600-625^{\circ} \mathrm{C}$ and $600-650{ }^{\circ} \mathrm{C}$ for migmatitic schist; the pressure is $\sim 8$ kbar. For amphibolite the temperature is $\sim 600-700{ }^{\circ} \mathrm{C}$ and pressure is $8-12 \mathrm{kbar}$. The estimated pressures and temperatures for the northeast Obudu rocks correspond to upper amphibolite to lower granulite facies metamorphism. The metamorphism occurred due to continent-continent collision during the Pan-African orogeny, most likely during the D1 deformational phase of the area. The recorded high pressures possibly resulted from crustal thickening in the area. P-T conditions for Pan-African orogeny in northeast Obudu area are in good agreement with P-T estimations for the Pan-African event in adjacent areas.
\end{abstract}

Key words: Pan-African orogeny, Nigeria, Obudu, upper amphibolite-lower granulite facies

\section{Introduction}

The Precambrian basement terrane in Nigeria is located in the Neo-Proterozoic to Early Phanerozoic Pan-African Trans-Saharan mobile belt that stretches from North Africa to Brazil, and has boundaries with the West African Craton to the

Addresses: *Corresponding author: M. Moazzen: University of Tabriz, 51664, Tabriz, Iran Phone: +98 411339 2679, e-mail: moazzen@tabrizu.ac.ir

Received: October 20, 2008, accepted: January 22, 2009 
west and the Gabon-Congo Craton to the southeast (Torquato and Cordani 1981; Caby et al. 1981; Boullier 1991; Attoh 1998). Basement rocks occurring in Nigeria are collectively referred to as the 'basement complex', and are exposed in three main regions, namely the southwestern region (Annor 1981; De Swardt 1953; Rahaman 1973; Odeyemi 1976, 1977), the southeastern region (Rahaman et al. 1981; Ekwueme and Ekwere 1989; Ekwueme 1990) and the north-central region (Olarewaju and Rahaman 1982) (Fig. 1a, b). Four episodes of deformation that are prior to, contemporaneous with, or even post-dating metamorphism within the complex have been established on the basis of a wealth of isotopic age data acquired over the years from the basement rocks (Grant et al. 1972; Oversby 1975; Pidgeon et al. 1976; Ogezi 1977; Van Breemen et al. 1977; Grant 1978; Mullan 1979; Ajibade 1980; Fitches et al. 1985; Ekwueme 1987; Ajibade 1988; Ekwueme and Caen-Vachette 1992; Dada et al. 1993; Ferré et al. 1995; Kroener et al. 2001; Ekwueme and Kröner 2006). Accordingly, the deformation and metamorphism that have affected the basement complex are products of four thermotectonic/ orogenic events that include the Liberian (2,700 Ma), the Eburnean (2,200 Ma), the Kibaran (1,300-1,400 Ma), and the Pan-African (450-1,100 Ma) ones. Each of these events has left structural imprints on the basement rocks of the complex (Ekwueme 1994). Many workers on the Nigerian basement, including McCurry (1971) and Rahaman (1976), are of the view that the Pan-African orogenic event was the latest, most pervasive and penetrative deformation episode, and that it completely obliterated earlier structures, primary fabrics and metamorphic assemblages of the complex. On the other hand, others, including Grant (1978), Onyeagocha and Ekwueme (1982), Ekwueme (1987), Oluyide (1988) and Ekwueme (1994) favor the view that although it was pervasive, the Pan-African event did not completely homogenize the rocks of the basement, so that traces of earlier structures still remain within the complex.

In southeastern Nigeria, published works on P-T evaluation of Pan-African metamorphism are scarce. Ferré et al. (2002) observed a predominantly granulite facies metamorphism for eastern Nigeria based on mineral paragenesis. However, details of the P-T estimation method is lacking in their paper. Mvondo et al. (2003) have calculated temperatures of $550{ }^{\circ} \mathrm{C}$ to $800{ }^{\circ} \mathrm{C}$ and pressures of 4 to $12 \mathrm{kbar}$ for Pan-African metamorphism of schist and gneiss from Yaounde, Cameroon. The present research focused on pelitic and basic rocks, which experienced the Pan-African metamorphic event in the Obudu Plateau area of southeastern Nigeria.

Petrographic features and mineral chemistry of the rocks are used to put constraints on the P-T conditions of the Pan-African orogeny in this area.

\section{Regional geologic setting}

Most parts of southeastern Nigeria are underlain by high-grade metamorphic rocks (Wright 1971; Ekwueme 1990, 2003; Ferré et al. 2002; Ejimofor et al. 1996). 

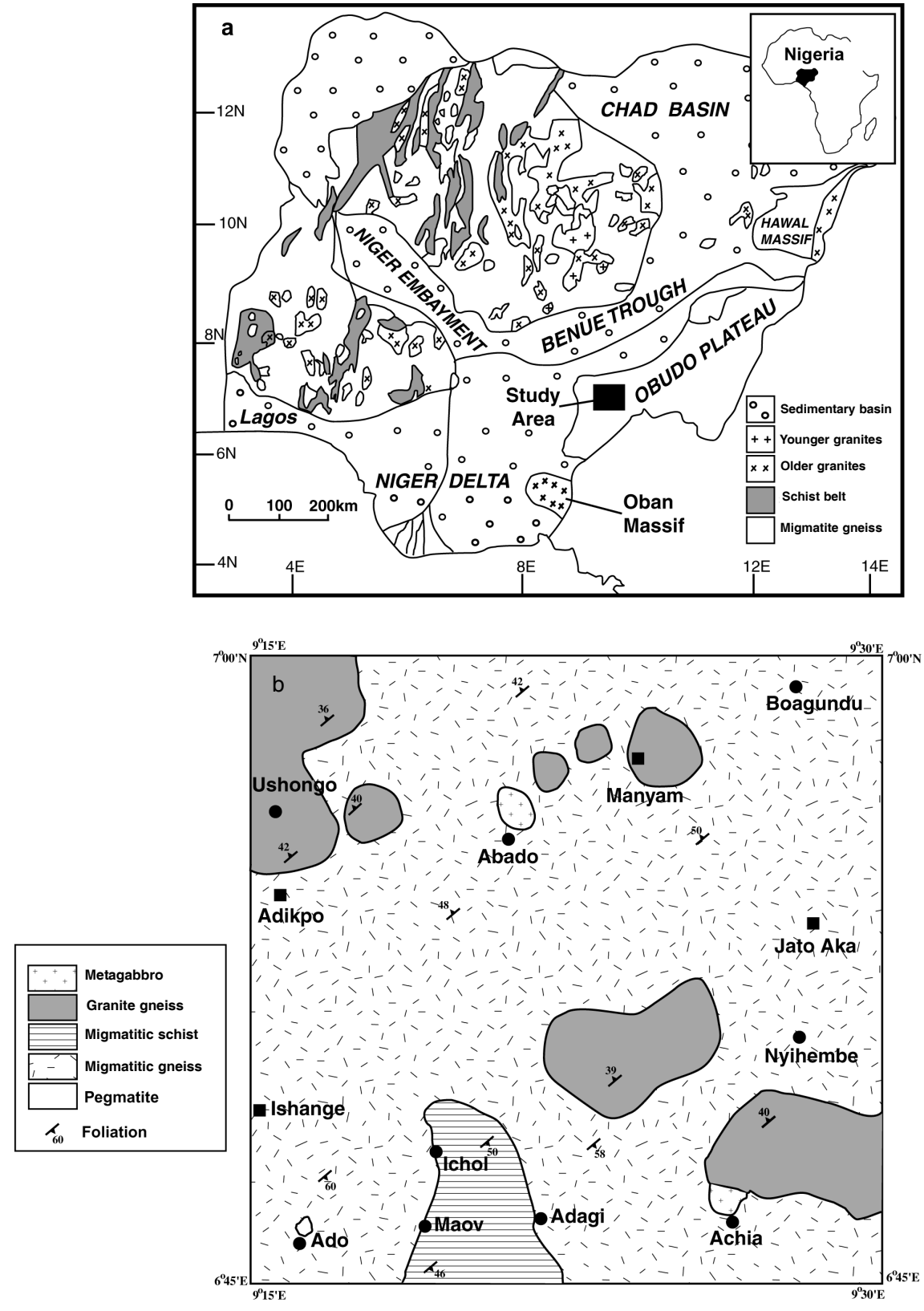

Fig. 1

a) Geologic map of Nigeria. The studied area is shown by a rectangle. b) Simplified geologic map of the northeast Obudu area 
The region is also often characterized by the preponderance of Pan-African granitic rocks, which account for more than $80 \%$ of the exposed bedrock, and by the general absence of well-developed schist belts similar to the ones in the southwestern and north-central regions of Nigeria. In fact, southeastern Nigeria appears to have more in common with Cameroon and the Central African fold belt than with the north-central and southwestern regions of the basement complex of Nigeria (Ekwueme 2003; Ephraim 2005). Consequently its evolutionary history is currently linked with that of the Pan-Africa mobile belt in Central Africa, north of the Congo Craton (Central African Foldbelt), also known as the Oubanguide or North Equatorial Foldbelt (Toteu et al. 2001; Toteu et al. 2004), and not with the Pan-Africa mobile belt at the margin of the West African Craton, known as the Dahomeyide Orogen. Accordingly, southeastern Nigeria has in recent times been associated with the continent-continent collision involving the northern edge of the Congo Craton as the passive margin and the Adamawa-Yadé and West Cameroon northern block as the active margin (Ephraim 2005; Toteu et al. 2004), instead of the continent-continent collision involving the passive continental margin of the West African Craton and the active continental margin of the Tuareg-Nigerian Shield/ Hoggar Craton (about $600 \mathrm{Ma})$.

\section{Field relations and petrography}

The area of investigation, northeast Obudu, constitutes part of the Bamenda Massif extensions into southeastern Nigeria (Fig. 1a). It is a high-grade metamorphic terrane that consists predominantly of quartzofeldspathic schist and gneiss that have been variably migmatized and intruded by rocks of acidicintermediate-basic compositions. These rocks form parts of the chains of major intrusions that extend from the Republic of Cameroon to the margin of the Benue Trough. The chains are structurally controlled by existing North-South PanAfrican trend within the basement. Rock types mapped within the northeast Obudu area, together with their structural orientations, are presented in Fig. 1b. The field/megascopic observations and the microscopic features of these rocks have been found to be consistent with its classification into four subgroups, namely:

1) Migmatitic gneiss

2) Migmatitic schist

3) Granite gneiss

4) Minor rocks (mainly amphibolite, metagabbro and dolerite)

Detailed descriptions of the field and petrographic characteristics of each rock type are provided below: 
Migmatitic gneiss

Quartzofeldspathic gneissic rocks that often display migmatitic characteristics constitute the dominant rock type occurring within the northeast Obudu area. The occurrence and structural orientation (the main foliation) of these rocks are shown in Fig. 1b. The migmatitic gneiss commonly occurs in intimate association with granite gneiss of the area. The heterogeneous deformation and migmatization that may have affected the migmatitic rock group resulted in the occurrence and intimate associations of the banded, semibanded and homogeneous types in such a manner that mapping each of these varieties as distinct units become almost impossible. Megascopically, the rock generally consists of the metamorphic host rock (paleosome) and leucocratic acid injections (leucosome).

The mineralogical modal composition of the migmatitic gneiss is presented in Table 1. The leucocratic mineral-rich phases are predominantly composed of variable proportion of quartz (23-33\%), plagioclase $(21-35 \%)$, orthoclase $(7-24 \%)$ and sometimes thin selvages of biotite. On the other hand, biotite (3-33\%), garnet $(1-13 \%)$, sillimanite $(\sim 1 \%)$ and sericite $(1-2 \%)$ occur as replacements/alteration products. From the petrographic observations it is clear that sillimanite probably replaced a former aluminosilicate (i.e. kyanite, andalusite), most likely kyanite. No kyanite was found in the studied rocks. Other mineral components of the

Table 1

Representative modal composition of the studied rocks

\begin{tabular}{lllll}
\hline & $\begin{array}{l}\text { Migmatitic } \\
\text { gneiss }\end{array}$ & $\begin{array}{l}\text { Migmatitic } \\
\text { schist }\end{array}$ & $\begin{array}{l}\text { Granite } \\
\text { gneiss }\end{array}$ & $\begin{array}{l}\text { Amphibolite } \\
\text { \& metagabbro }\end{array}$ \\
\hline Quartz & 30 & 28 & 27 & 6 \\
Plagioclase & 35 & 25 & 23 & 26 \\
K-feldspar & 20 & 12 & 35 & 3 \\
Biotite & 5 & 21 & 12 & 9 \\
Garnet & 1 & 10 & & \\
Sillimanite & 1 & $<1$ & & \\
Hornblende & & $<1$ & & 51 \\
Orthopyroxene & 1 & & & \\
Clinopyroxene & & & & \\
Olivine & & & 2 & \\
Chlorite & & $<1$ & $<1$ & 1 \\
Titanite & $<1$ & $<1$ & $<1$ & 2 \\
Epidote & 6 & 1 & $<1$ & \\
Zircon & $<1$ & $<1$ & $<1$ & \\
Allanite & & & $<1$ & \\
Apatite & $<1$ & & $<1$ & \\
Sericite & & 2 & $<1$ & 2 \\
Opaque & $<1$ & & 99 & 100 \\
Total & 99 & 99 & & \\
\hline
\end{tabular}


rock include orthopyroxene, titanite, epidote, apatite, zircon and opaque oxide. The quartz, consisting of irregularly shaped crystals with their lenticular outlines parallel to the fabric of the rock, often contains inclusions of biotite, plagioclase and opaque oxides. Interstitial quartz is also present and together with the plagioclase minerals constitute the groundmass mosaic of most of the thin sections examined. The migmatitic gneiss contains both plagioclase and $\mathrm{K}-$ feldspar. Plagioclase dominates with an average modal percentage of about $27 \%$. Sericitization of the plagioclase minerals is rampant and is obvious from the rimming and inclusions of sericite minerals within the plagioclase minerals. $\mathrm{K}$ feldspars are subordinate to both plagioclase and quartz (see Table 1), and they are dominantly orthoclase with very little or no microcline. Biotite makes up about $5 \%$ of the migmatitic gneiss volume as is discernible from Table 1 . It appears to be of two generations. The early or first generation biotites display anhedral, slender and prismatic habit with occasional stumpy laths that may sometimes be kinked, whereas the late or second generation biotite is mainly made up of isolated subhedral crystals that are tabular in form as well as randomly distributed, sometimes cross-cutting each other. The biotite, especially the first generation, occasionally contains inclusions of apatite. Garnet crystals make up about $1 \%$ of the rock mode (Table 1) and are commonly wrapped around the foliation of the first generation biotite (Fig. 2a to 2d). Sillimanite crystals also occur within the rock as a minor constituent of about $1 \%$ (see Table 1 ). They are generally observable as finely felted fibroid aggregate of acicular fibrolite that form contorted lenses. Sometimes they appear to be growing on biotite crystals. In addition, traces of orthopyroxene occur in textural equilibrium with the already mentioned assemblages.

\section{Migmatitic schist}

Banded schist and locally homogeneous varieties constitute one of the major rock types occurring within northeast Obudu (Fig. 1b). Like the gneissic rocks, the schist is frequently migmatitic and forms part of the basement rocks into which the felsic and mafic plutons are intruded. Most outcrops of migmatitic schist within northeast Obudu are extensively weathered. In the southern Obudu area, Ekwueme (1991) observed interbanding on a megascopic scale of garnet sillimanite gneiss with quartzitic units, and explained such occurrence to be indicative of the sedimentary origin of these rocks. No contact relationships were observed in the field between the migmatitic gneiss and schist but spatial configurations of both rock types suggest that the schist may be relatively younger and was probably supracrustal on the gneissic rocks of the area.

Fig. $2 \rightarrow$

Back-scattered images from different rock types in northeast Obudu. Mineral name abbreviations are after Kretz (1983). a to d, migmatite gneiss; e and f, migmatite schist; g, granite gneiss and h, amphibolite 


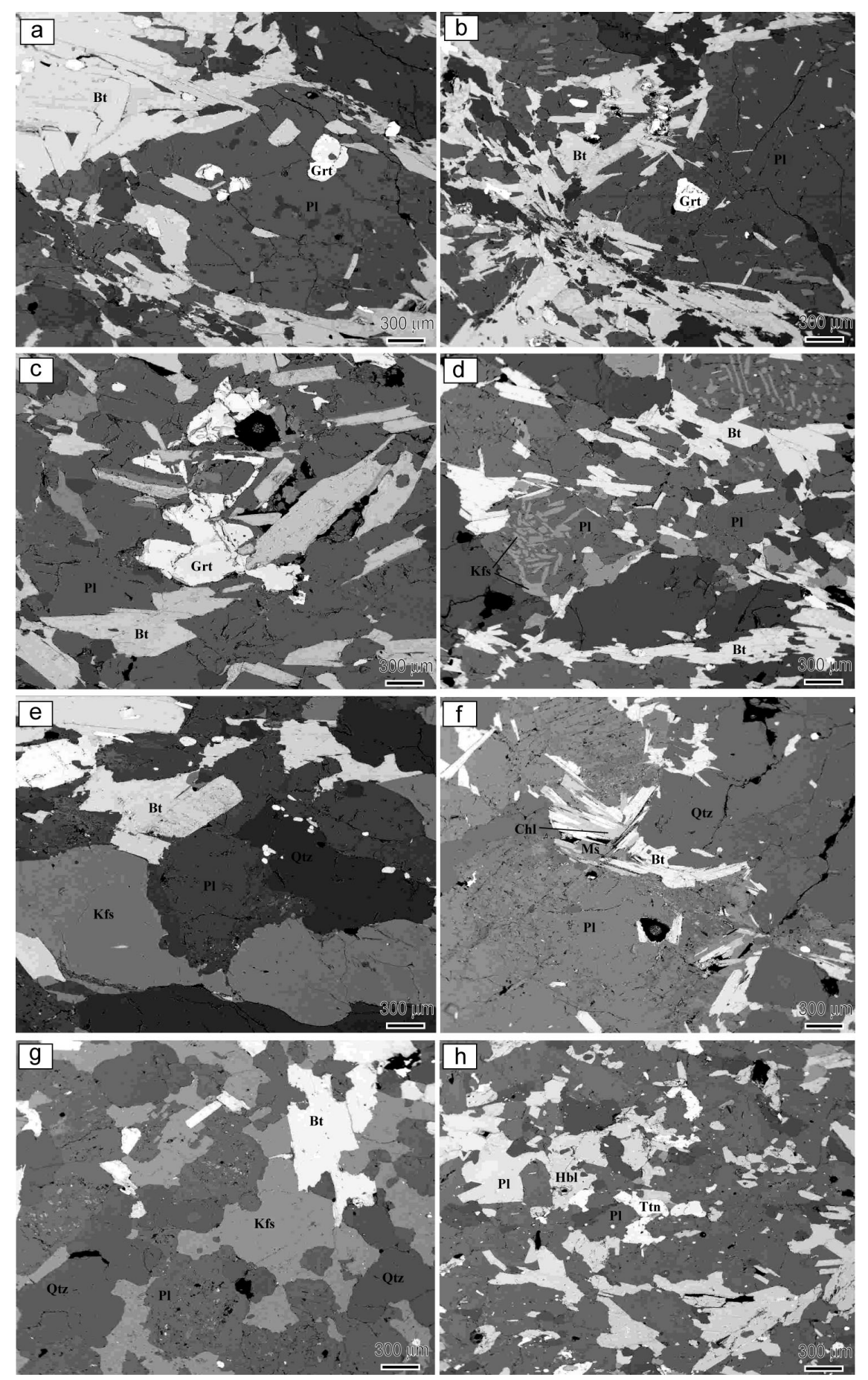

Central European Geology 51, 2008 
However, only geochronological data can lead to a better conclusion on the chronology and structural relationship between these two types of rocks within the area.

The modal composition of the migmatitic schist is presented in Table 1. The leucocratic minerals of the migmatitic schist include quartz (26-28\%), plagioclase (20-27\%) and K-feldspar (12-17\%), whereas the mesocratic parts are commonly made up of biotite (20-22\%) and garnet (4-18\%). In addition, sillimanite $(\sim 1 \%)$, epidote $(1-2 \%)$ and sericite $(1-3 \%)$ occur in minor concentrations, while chlorite, hornblende, titanite and zircon constitute the accessory mineral phase. Plagioclase has a modal average proportion of about $20 \%$ (Table 1). Plagioclase occurs in a matrix of interlocking grains with quartz and subordinate K-feldspar K-feldspar is subordinate to plagioclase and in some samples orthoclase dominates, while in others microcline is the dominant K-feldspar mineral. Biotite is the dominant mafic mineral present and is often associated with garnet. Garnet occurs consistently in all the samples of migmatitic schist examined.

The grains are mostly porphyroblastic with subhedral outline. Sometimes the garnet grains exhibit embayed boundaries and often harbor many inclusions, mostly of quartz, mica and opaque oxides (Fig. 2e to $2 \mathrm{f}$ ). Sillimanite occurs in some thin sections as a minor component of the rock. Where these occur they often appear to be growing on biotite grains.

\section{Granite gneiss}

Several intrusive granitoid bodies of obvious plutonic character are well exposed as oval or dome-shaped bodies sporadically distributed in the basement complex rocks at both the northern edge and the southeastern regions of the study area (Fig. 1b). These granitoid bodies are completely surrounded by the migmatitic gneiss. With very few exceptions, outcrops of the rock generally exhibit similar features and are typically made up of fine- to medium-grained porphyritic granite gneiss near the marginal areas where it is difficult to separate from the surrounding migmatite gneiss complex rocks, due to the presence of narrow contact aureoles with the country rock. The granite gneiss of the area is generally homogeneous, weakly to strongly foliated and massive. The mean of the modal composition of the granite gneiss of northeast Obudu presented in Table 1 indicates that the feldspar minerals altogether constitute more than 50\% of the rock volume, followed by quartz and biotite, while chlorite and epidote taken together constitute barely 3\% of the rock mode (Fig. $2 \mathrm{~g}$ ). Quartz ranks next to K-feldspar with an average modal proportion of about $27 \%$, and generally exhibits a porphyroblastic habit. Biotite appears to be the major mafic mineral and it constitutes about $12 \%$ of the rock volume. Chlorite, epidote and sericite are alteration products in all the samples of the rock studied. The accessory-mineral phase comprising allanite, sericite, sphene, zircon apatite and opaque oxides make up less than $1 \%$ of the rock volume. 


\section{Minor rocks with basic composition}

The minor rocks include amphibolite, metagabbro and dolerite. While metagabbro and amphibolite occur in the migmatitic gneiss of the area, dolerite occurs as enclaves within the granite gneiss. Amphibolite and metagabbro occur within the migmatitic gneiss of northeast Obudu as basic lenses of variable dimension and orientations. Sometimes the lenses are sheared and deformed to produce dismembered enclaves within the host rock.

Amphibolites and metagabbros of the area are mineralogically similar. Metagabbros are coarser grained and lack preferred orientation of the minerals. The modal composition of representative samples of the amphibolitic rock, also presented in Table 1, show that the rock is generally made up of $48-51 \%$ hornblende, $24-26 \%$ plagioclase, $9-10 \%$ biotite and less than $10 \%$ of quartz, Kfeldspars, opaque oxide, epidote and titanite (Fig. $2 \mathrm{~h}$ ). The dolerites of the area are fine- to medium-grained. The modal compositions in Table 1 show that the dolerites are essentially composed of plagioclase (40-42\%), orthopyroxene (38-39\%), clinopyroxene (7-9\%) and olivine (9\%). The accessory mineral phases are mainly made up of opaque oxides $(1-4 \%)$.

\section{Mineral chemistry}

Minerals in optically well-defined, otherwise representative samples from schist, gneiss and amphibolite were analyzed by means of electron microprobe analysis. A JEOL JXA-8900A microprobe in the Indiana University was used. Operating conditions were maintained at an accelerating voltage of $15 \mathrm{kv}$ and a beam current of $10 \mathrm{nA}$. The raw data were analyzed by the built-in program, which is based on the ZAF procedure.

Mineral and synthetic reference standards were used as standard calibrations. Results are summarized in Table 2.

Garnet: Garnets were analyzed in migmatitic schist and gneiss; in both rock types the garnets are rich in almandine. The composition of garnets in migmatitic gneiss is $\mathrm{Alm}_{62-64} \mathrm{Pyp}_{7-7.6} \mathrm{Grs}_{19.3-23.2} \mathrm{Sps}_{7.5-10.5}$ and $\mathrm{Alm}_{69-77} \mathrm{Pyp}_{10-17} \mathrm{Grs}_{6.6-10}$ $\mathrm{Sps}_{2.7-9}$ in migmatitic schist. Garnets in these rocks do not exhibit distinct chemical zoning but they are slightly depleted in pyrope content at the rims of the crystals. This feature is considered in thermobarometrical calculations.

Feldspars: The composition of plagioclases in amphibolite and migmatitic gneiss is similar, and corresponds to an andesine-oligoclase ( $\left.\mathrm{Ab6}_{3-71} \mathrm{An}_{29-37}\right)$ composition, while plagioclase in the migmatitic schist is slightly richer in albite $\left(\mathrm{Ab}_{67-77} \mathrm{An}_{23-33}\right)$. The composition of plagioclases in granite gneiss is close to the albite end-member $\left(\mathrm{Ab}_{84-96} \mathrm{An}_{4-16}\right)$. K-feldspars were analyzed in the migmatitic schist. They are very close to orthoclase end-member.

Mica: The formula unit of mica is calculated on the basis of 22 oxygens, considering all $\mathrm{Fe}$ as $\mathrm{Fe}^{2+}$. Biotites are rich in $\mathrm{Fe}$, and $\mathrm{Mg} \#(\mathrm{Mg} / \mathrm{Mg}+\mathrm{Fe})$ is 0.3. $\mathrm{Al}^{\mathrm{IV}}$ in biotites from migmatitic gneiss is $1.225-1.271,1.175-1.203$ in biotites from 


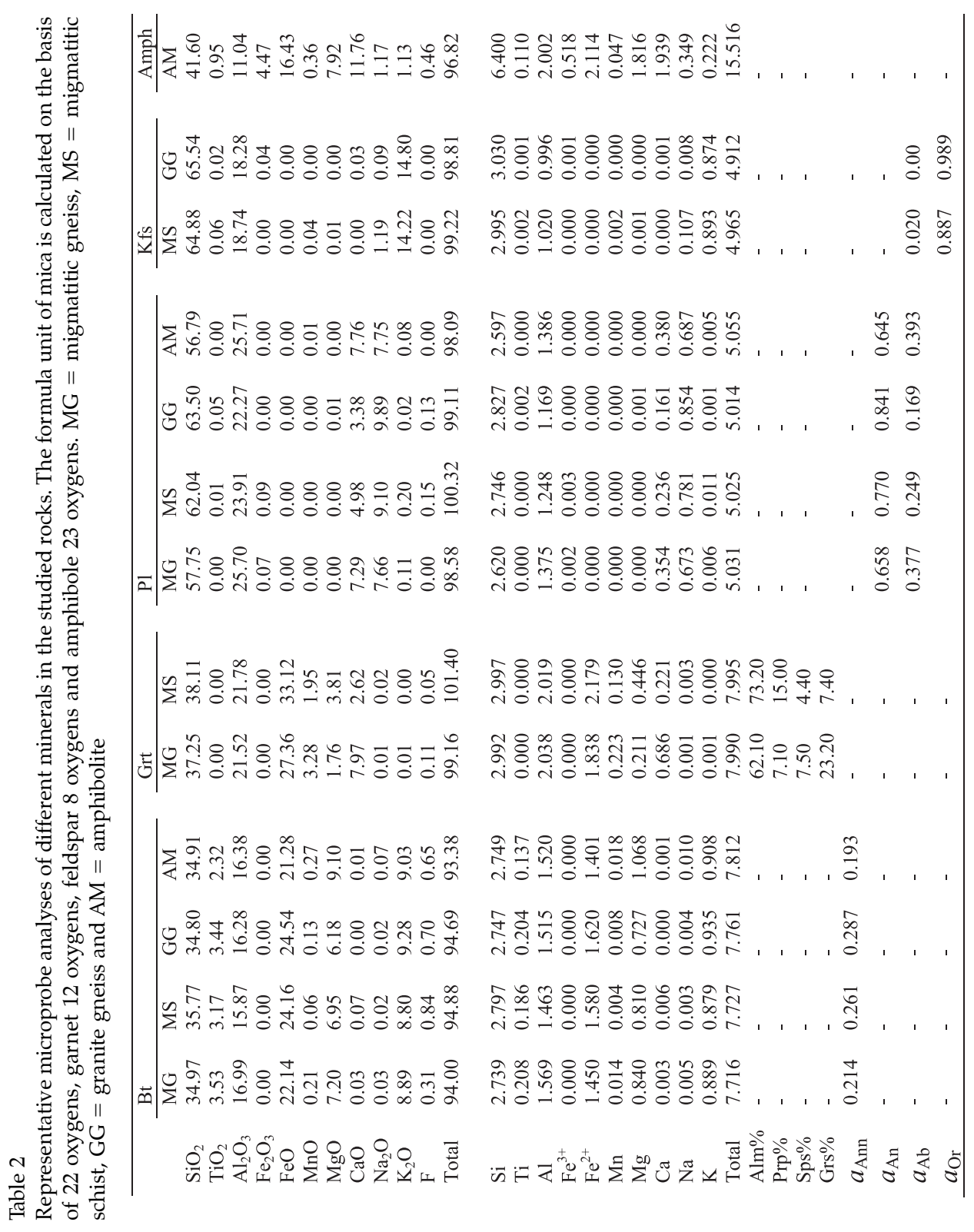


migmatitic schist, $1.217-1.253$ in biotites from granite gneiss, and 1.228-1.251 in biotites from amphibolite. The highest $\mathrm{Ti}$ content belongs to biotites from migmatitic gneiss and granite gneiss $(\sim 0.2$ atom per formula unit, apfu $)$ and the lowest content belongs to biotites from amphibolite (0.137-0.145). F content of biotites in the migmatitic schist is about 0.9 , which is higher than the biotite Fcontent in the other rocks (0.028-0.789 apfu).

Amphibole: Amphiboles were analyzed in amphibolite from the Obudu area. Representative microprobe data are provided in Table 2. Cations are calculated based on 23 atoms of oxygen and the $\mathrm{Fe}^{2+} / \mathrm{Fe}^{3+}$ ratio is estimated using the stoichiometric approach (Droop 1987). The studied amphiboles have values of $\mathrm{NaM} 4<0.67$ and $(\mathrm{Ca}+\mathrm{Na}) \mathrm{M} 4>1.34$ and are calcic amphiboles according to the classification of Leake (1978). $\mathrm{Mg \#}$ is $0.462-0.502$ for the studied amphiboles. They show a ferrohornblende and hastingsite composition on the $\mathrm{Mg \# /Si}$ diagram (Fig. 3) and magnesiohornblende to tschermakite composition on the $\mathrm{Ti} / \mathrm{Al}^{\mathrm{IV}}$ diagram of Leake et al. (1997) (Fig. 4a). Amphiboles plot between the hornblende and pargasite substitution vectors in Fig. $4 \mathrm{~b}$ (Hietanen 1974). The F content of the amphiboles is $0.038-0.464$.

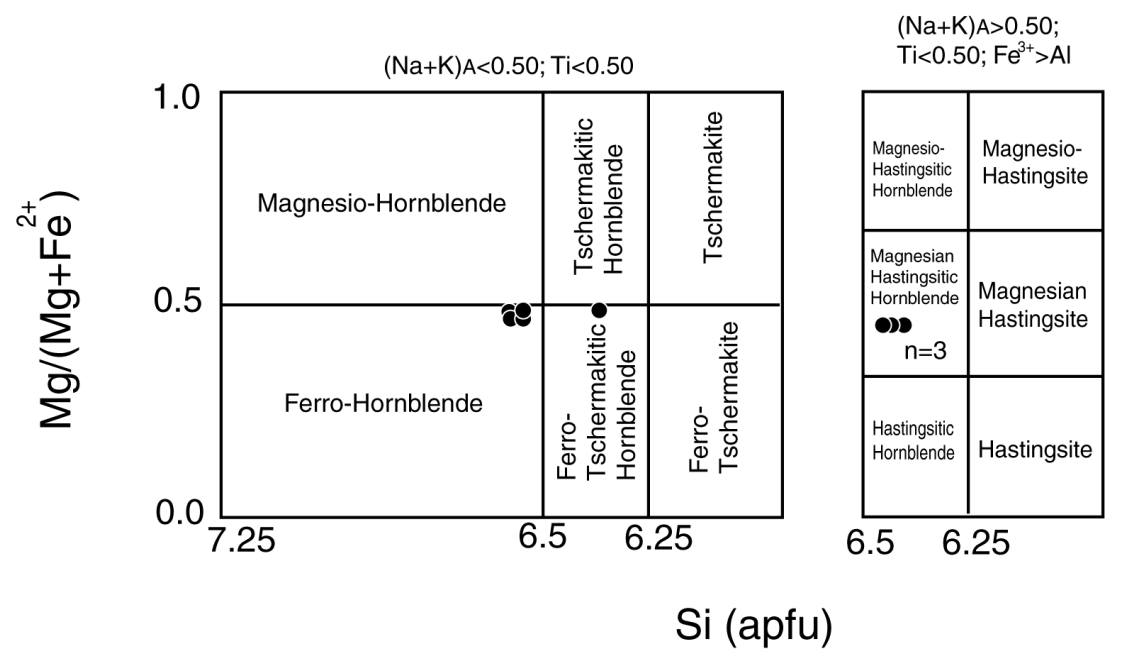

Fig. 3

$\mathrm{Mg} /\left(\mathrm{Mg}+\mathrm{Fe}^{2+}\right)$ versus Si diagram for amphiboles indicates a ferrohornblende to hastingsite composition for the studied amphiboles

\section{Pressure and temperature estimation}

Pressure and temperature of formation of the studied rocks were estimated using conventional geothermobarometric methods. Fe-Mg exchange between garnet and biotite thermometer using calibrations of Bhattacharya et al. (1992) 

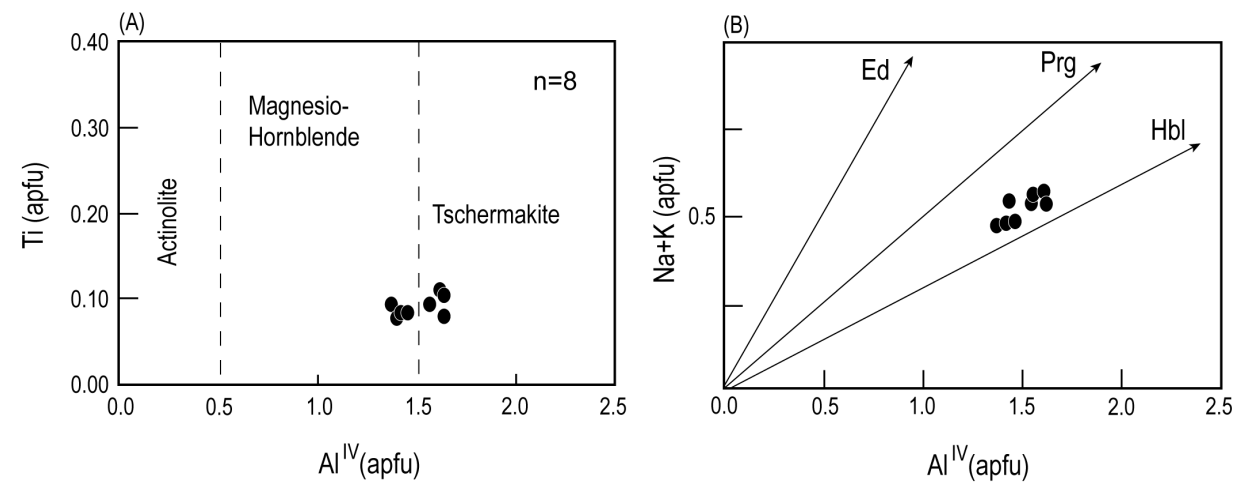

Fig. 4

Ti versus $\mathrm{Al}(\mathrm{IV})$ and $\mathrm{Na}+\mathrm{K}$ versus $\mathrm{Al}(\mathrm{IV})$ (after Hietanen 1974) for the studied amphiboles which show magnesio-hornblende to tschermakite composition. Amphiboles from amphibolite in northeast Obudu plot along the pargasite-hornblende exchange vector

and Thompson (1976) was applied to migmatitic schist and migmatitic gneiss. Solution models of Helffrich and Wood (1989) and Ganguly and Saxena (1984) are used for garnets. A temperature of $600-625{ }^{\circ} \mathrm{C}$ was calculated for migmatitic gneiss and $700-860{ }^{\circ} \mathrm{C}$ for migmatitic schist. Temperatures estimated using calibrations by Ferry and Spear (1978), Pigage and Greenwood (1982) and Hodges and Spear (1982) are higher than those from calibrations of Bhattacharya et al. (1992) and Thompson (1976), while temperatures from the calibration of Indares and Martignole (1985) are systematically lower than the results from the other calibrations. The higher temperatures are an artifact of the high Ti content in biotite (Indares and Martignole 1985). The lower temperatures are due to the introduction of interaction parameters for $\mathrm{Ti}$ and $\mathrm{Al}^{\mathrm{vi}}$ in biotite and $\mathrm{Mn}$ and $\mathrm{Ca}$ in garnet, into the original calibration of Ferry and Spear (1978). The calibration of Indares and Martignole (1985) possibly over-corrects the effect of the minor components. The temperatures given by the Bhattacharya et al. (1992) calibration, which uses the mixing parameters for pyrope-almandine asymmetric regular solution after Hackler and Wood (1984), is intermediate to those of Indares and Martignole (1985) and Ferry and Spear (1978). These temperatures are taken to best estimate the temperatures of garnet-biotite-bearing rocks of the Obudu area. The behavior of sillimanite is not well understood in the studied rocks. It replaces other minerals (mainly biotite) and appears as a fibrous aggregate, making up less than $1 \%$ of the rocks (Table 1). Therefore the GASP (garnet-sillimanite-quartz-plagioclase) barometer cannot be used to estimate the pressure unequivocally. However, the Koziol and Newton (1988) calibration was also attempted. Garnets with highest Mg contents and biotites with highest Ti content were used to find the possible peak metamorphic pressure. Migmatite gneiss gives a pressure of 7.6-10.9 kbar and migmatite schist of 9.5-14 kbar. 
Because of the uncertain status of sillimanite in the studied rocks these pressures were not used to constrain the P-T condition of northeast Obudu. For amphibolite the hornblende-plagioclase thermometer of Holland and Blundy (1994) and the thermometer of Colombi (1989) were used. The hornblendeplagioclase thermometer calibrated by Blundy and Holland (1990) and Holland and Blundy (1994) is constructed by using the $\mathrm{Al}^{\mathrm{iv}}$ content of amphibole coexisting with plagioclase in silica-saturated rocks. The overall standard error for this thermometer is $38^{\circ} \mathrm{C}$. Considering the complex chemical composition of amphiboles and possibility of several miscibility gaps among amphibole endmembers and an uncertain $\mathrm{Fe}^{3+} / \mathrm{Fe}_{\text {total }}$ ratio using microprobe data, temperatures obtained from plagioclase-hornblende thermometer are not very precise.

Considering the presence of quartz in amphibolites the edenite-tschermakite calibration of the thermometer was used, which gives temperatures of $680^{\circ} \mathrm{C}$ for amphibolite. Using the semi-quantitative thermobarometer of Ernst and Liu (1998) a temperature of $600{ }^{\circ} \mathrm{C}$ and pressure of 8-12 kbar can be considered for these rocks (Fig. 5). The thermometer of Colombi gives a temperature of $\sim 700^{\circ} \mathrm{C}$ for the amphibolite, which is in good agreement with temperatures from the hornblende-plagioclase thermometer. The P-T condition for migmatitic schist was estimated using multi-equilibria calculations and THERMOCALC v.2.4. (Powell

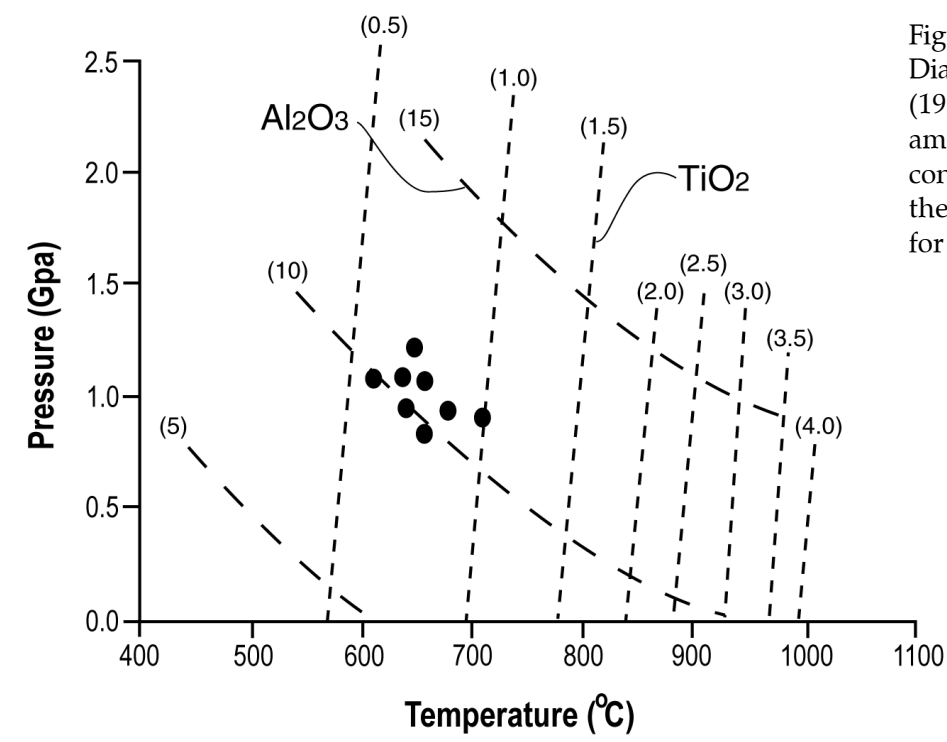

and Holland 1988). There is no suitable mineral paragenesis in granite gneiss to estimate P-T conditions of their formation, but since amphibolite appears in the form of lenses within these rocks, more likely the P-T conditions estimated for amphibolite can also be considered for granite gneiss. The P-T results are summarized in Table 3. 
Table 3

Summary of P-T estimation for the southeastern Nigeria rocks

\begin{tabular}{|c|c|c|c|}
\hline & Amphibolite & Migmatitic schist & Migmatitic gneiss \\
\hline \multicolumn{4}{|l|}{ Thermometry } \\
\hline Grt-Bt (Bhattacharya et al. 1992) & & $790^{\circ} \mathrm{C}$ & $615^{\circ} \mathrm{C}$ \\
\hline Hbl-Pl (Holland and Blundy 1994) & $700{ }^{\circ} \mathrm{C}$ & & \\
\hline Amph (Colombi 1989) & $710^{\circ} \mathrm{C}$ & & \\
\hline \multicolumn{4}{|l|}{ Barometry } \\
\hline $\begin{array}{l}\text { Al in hornblende (Johnson and Rutherford } \\
\text { 1989) }\end{array}$ & $5 \mathrm{kbar}$ & & \\
\hline \multicolumn{4}{|l|}{ Thermobarometry } \\
\hline $\begin{array}{l}\text { THERMOCALC v.2.4. (Powell and } \\
\text { Holland 1988) } \\
\text { Al-Na in hornblende (Ernst and Liu, 1998) }\end{array}$ & $8-12 \mathrm{kbar}$ & $\begin{array}{l}\mathrm{P}=7 \pm 2 \mathrm{kbar} \\
\mathrm{T}=615 \pm 50^{\circ} \mathrm{C}\end{array}$ & \\
\hline $\begin{array}{l}\text { Mineral component activity values used in } \\
\text { THERMOCALC calculations }\end{array}$ & & $\begin{array}{l}\text { ann }=0.12, \mathrm{phl}=0.0161, \\
\text { east }=0.014 \\
\text { alm }=0.37, \mathrm{py}=0.0058, \\
\mathrm{gr}=0.00074 \\
\text { or }=0.90, \mathrm{an}=0.38, \mathrm{ab}=0.67\end{array}$ & \\
\hline
\end{tabular}

\section{Discussion and Conclusions}

The studied area in northeast Obudu, the Bamenda Massif, is a part of the Eastern Nigeria Terrane. The existence of two main terranes in Nigeria, i.e. the Western and Eastern Terranes, was proposed by Ferré et al. (1995, 2002). Eastern Nigeria was intruded by several Proterozoic plutons (e.g. Snelling 1964; Tougarinov et al. 1968; Caen-Vachette and Umeji 1983; Umeji and Caen-Vachette 1984; Ferré et al. 2002). Two main deformational phases, D1 and D2, are recognized in the Eastern Nigeria Terrane and in other Pan-African terranes (e.g. Ferré et al. 2002; Mvondo et al. 2003). Ferré et al. (2002) consider a possible monocyclic tectonometamorphic evolution for Eastern Nigeria with granulite facies conditions. They consider the peak of metamorphism contemporaneous with D1 deformation (ca. $64 \mathrm{Ma}$ ), which occurred due to the easterly displacement of an early nappe. Ephraim et al. (2006) also have reported a possible granulite facies metamorphism for these rocks. Mvondo et al. (2003) consider D1 deformation phase as a compressional phase due to collision and D2 phase as an extensional phase. The metamorphic rocks in the Eastern Nigeria Terrane and the Obudu area are considered to reach metamorphic grades up to upper amphibolite facies by Onyeagocha and Ekwueme (1990), while Ferré et al. (2002) and Ukwang et al. (2003) concluded that metamorphism in the Eastern Nigeria Terrane extended to granulite facies. Ekwueme and Kröner (2006) have calculated a single zircon age of $574 \pm 10 \mathrm{Ma}$ for gneiss of the Obudu Plateau. They conclude that the Pan-African high-grade event in the area was coeval with the formation of granulites in Cameroon, Togo and Ghana. This study indicates a formation 
temperature for migmatite gneiss of the area of $600-625{ }^{\circ} \mathrm{C}$. P-T conditions for migmatite schist are $600-800{ }^{\circ} \mathrm{C}$ and $4-9$ kbar and $600-700{ }^{\circ} \mathrm{C}$ and $8-12 \mathrm{kbar}$ for amphibolite. Probably lower temperatures show re-equilibration during thermal relaxation; therefore low temperatures were not used to estimate the peak of metamorphic conditions. It can be seen that amphibolite shows higher temperatures than migmatitic gneiss. Most likely, migmatitic gneiss has experienced a later re-equilibrium during solidification of the generated partial melts and during thermal relaxation or exhumation. The estimated pressures and temperatures for northeast Obudu rocks correspond to upper amphibolite to lower granulite facies metamorphism. These results are in agreement with the P$\mathrm{T}$ conditions estimated for Pan-African orogeny from other areas (e.g. Yaounde Nappe, Cameroon - Mvondo et al. 2003; Ukwortug area of Obudu - Ukwang et al. 2003; Agou Massif of southern Togo - Agbossoumonde et al. 2004; Ghana, Togo and Benin - Castaing et al. 1993; Dahomeyide - Attoh 1998a, b). Estimated P-T conditions for migmatitic schist and amphibolite (where both $\mathrm{P}$ and T estimates

Fig. 6

P-T conditions of formation of the studied rocks. The schematic P-T path is modified after Affaton et al. (2000) Aluminosilicates equilibria and granite melting curves are provided for comparison. Granulite facies metamorphic age (ca. $574 \mathrm{Ma}$ ) is from Ekwueme and Kröner (2006)

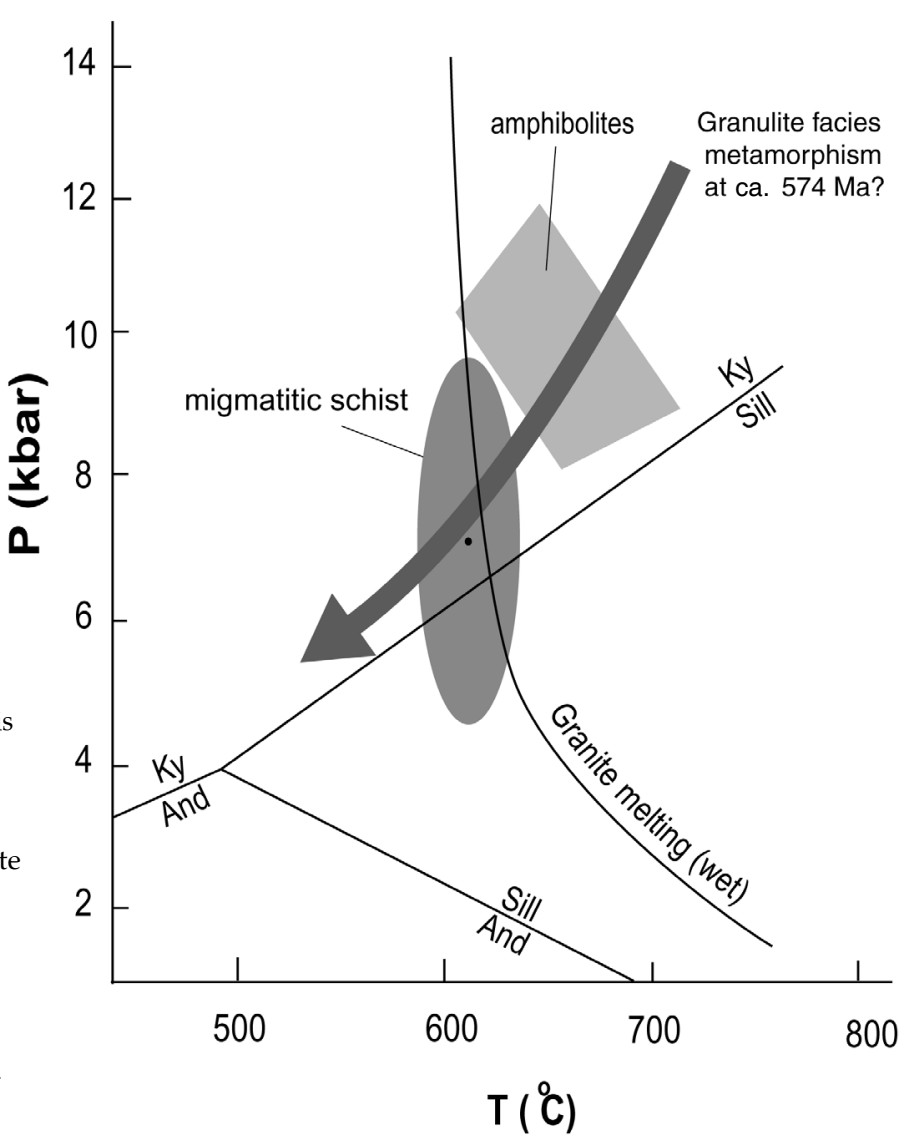

Central European Geology 51, 2008 
are available) are plotted on the P-T diagram of Fig. 6. Although the P-T path for the Obudu area is not very certain; probably these rocks have experienced the same P-T evolution as granulite facies rocks from Kabye Massif of northern Togo during the Pan-African orogeny (Affaton et al. 2000). A pressure of about $8 \mathrm{kbar}$ (average of pressures calculated in this contribution, considering P estimation uncertainties) corresponds to a depth of $30 \mathrm{~km}$ (assuming an average crustal density of $\sim 2700 \mathrm{~kg} / \mathrm{m}^{3}$ ). This shows a possible crustal thickening probably similar to Phanerozoic continent-continent collision of the Himalaya type (e.g. Maboko 1977).

The main conclusions that may be made from this study are:

- Metamorphic rocks from northeast Obudu have undergone upper amphibolite to granulite facies metamorphism;

- This metamorphism occurred due to continent-continent collision;

- High pressures estimated show a possible crustal thickening due to collision;

- The P-T results provided here are in good agreement with P-T condition estimated for Pan-African orogeny in other areas.

\section{Acknowledgements}

We appreciate the assistance and input from colleagues in the University of Calabar. The GPS used for the field study was kindly supplied by Dr. M. I Oden. Dr. Eno Ebenso and Mr. David Inyang are also commended for useful suggestions. Mr. I. C. Adamu of the Department of Geology, Benue State College of Remedial/Advanced studies assisted with the fieldwork. Mr. Keewook Yi of the Indiana University carried out the microprobe analysis on which the work is based. We thank János Haas and Gábor Schmiedl for editorial handling of the manuscript. A thoughtful review by Balázs Koroknai improved the manuscript.

\section{References}

Affaton, P., A. Kroener, K.F. Seddoh 2000: Pan-African granulite formation in the Kabye Massif of northern Togo (West Africa): Pb-Pb zircon ages. - International Journal of Earth Sciences, 88, pp. 778-790.

Agbossoumonde, Y., S. Guillot, R.P. Menot 2004: Pan-African subduction-collision event evidenced by high-P coronas in metanorites from the Agou massif (southern Togo). - Precambrian Research, 135/1-2, pp. 1-21.

Ajibade, A.C. 1980: Geotectonic evolution of the Zungeru region, Nigeria. - Unpublished PhD thesis, University of Wales, Aberystwyth.

Ajibade, A.C. 1988: Structural and tectonic evolution of the Nigerian basements with special reference to NW Nigeria. - International Conference on Proterozoic geology and tectonics of high-grade terrain, University of Ile-Ife, Nigeria, $22 \mathrm{p}$.

Annor, A.E. 1981: Geology of the area around Okene, S. W. Nigeria. - Unpublished PhD thesis. University of Wales, Swansea, U.K.

Attoh, K. 1998a: High-pressure granulite facies metamorphism in the Pan-African Dahomeyide orogen, West Africa. - Journal of Geology, 106/2, pp. 236-278. 
Attoh, K. 1998b: Models for orthopyroxene-plagioclase and other corona reactions in metanorites, Dahomeyide orogen, West Africa. - Journal of Metamorphic Geology, 16/3, pp. 345-362.

Bhattacharya, A., L. Mohanty, A. Maji, S.K. Sen, M. Raith 1992: Non-ideal mixing in the phlogopiteannite binary: constraints from experimental data on $\mathrm{Mg}$-Fe partitioning and a reformulation of the biotite-garnet thermometer. - Contributions to Mineralogy and Petrology, 111, pp. 87-93.

Blundy, M.J., T.J.B. Holland 1990: Calcic amphiboles equilibria and a new amphibole-plagioclase geothermometer. - Contributions to Mineralogy and Petrology, 104, pp. 208-224.

Boullier, A.M. 1991: The Pan-African belt in the Hoggar shield (Algeria, Mali and Nigeria): a review. - In: Dalmeyer, R.D, J.P. Lécorché (Eds): The West African Orogen and Circum-Atlantic Correlatives. Springer Verlag, Berlin. pp. 85-105.

Caby, R., K.L.M. Betrand, R. Black 1981: Pan African ocean closure and continental collision in the Hoggar-Iforas segment central Sahara. - In: Kroner, A. (Ed.): Precambrian Plate Tectonics. Elsevier, Amsterdam. pp. 403-437.

Caen-Vachette, M., A.C. Umeji 1983: Whole rock Rb-Sr dating of two monzogranites in southern Nigeria and their implications on the age of the Pan-African orogenic cycle. - Journal of African Earth Sciences. 1, pp. 339-342.

Castaing, C., C. Triboulet, J.L. Feybesse, P. Chevremont 1993: Tectonometamorphic evolution of Ghana, Togo and Benin in the light of the Pan-African/Brasiliano orogeny. - Tectonophysics, 218/4, pp. 323-342.

Colombi, A. 1989: Métamorphisme et géochimie des roches mafiques des Alpes ouest-centrales (géoprofil Viège-Domodossola-Locarno). - Mémoires de Géologie, Lausanne. 4, pp. 1-261.

Dada, S.S., I.A. Tubosun, J.R. Lancelot, A.U. Lau 1993: Late Archaean U-Pb age for the reactivated basements of northeastern Nigeria. - Journal of African Earth Sciences, 16, pp. 405-412.

De Swardt, A.M. 1953: The geology of the country around Ilesha, Western Nigeria. - Bulletin of the Geological Survey of Nigeria, $23 \mathrm{p}$.

Droop, G.T.R. 1987: A general equation for estimating Fe3+ concentrations in ferromagnesian silicates and oxides from microprobe analyses, using stoichiometric criteria. - Mineralogical Magazine, 51, pp. 431-453.

Ejimofor, O.C., A.C. Umeji, U.M. Turaki 1996: Petrology and major element geochemistry of the basement rocks of northern Obudu area, eastern Nigeria. - Journal and Mining and Geology, 32, pp. 1-9.

Ekwueme, B.N. 1987: Structural orientation and Precambrian deformational episodes of Uwet area, Oban massif, SE Nigeria. - Precambrian Research, 34, pp. 269-289.

Ekwueme, B.N. 1990: Rb-Sr ages and petrologic features of Precambrian rocks from the Oban Massif, southeastern Nigeria. - Precambrian Research, 47, pp. 271-286.

Ekwueme, B.N. 1991: Geology of the area around Obudu Cattle Ranch, southeastern Nigeria. Journal of Mining and Geology, 27, pp. 129-134.

Ekwueme, B.N. 1994: Structural features of southern Obudu Plateau, Bamenda massif, SE Nigeria: preliminary interpretations. - Journal of Mining and Geology, 30/1, pp. 45-59.

Ekwueme, B.N. 2003: The Precambrian Geology and Evolution of the Southeastern Nigerian Basement Complex. - University of Calabar Press, Calabar. 135 p.

Ekwueme, B.N., M. Caen-Vachette 1992: Kibaran charnockites from the Oban massif in the PanAfrican belt of Nigeria. - IGCP No. 255. Newsletter/Bulletin, 4, pp. 67-71.

Ekwueme, B.N., S.J. Ekwere 1989: The geology of the eastern section of Oban massif, SE Nigeria. Journal of Mining and Geology, 25, pp. 317-329.

Ekwueme, B.N., A. Kröner 2006: Single zircon ages of migmatitic gneisses and granulites in the Obudu Plateau: Timing of granulite-facies metamorphism in southeastern Nigeria. - Journal of African Earth Sciences, 44, pp. 459-469.

Ephraim, B.E. 2005: Petrology and geochemistry of basement rocks in northeast Obudu area, Bamenda Massif, southeastern Nigeria. - Unpublished PhD thesis, University of Calabar, $367 \mathrm{p}$.

Ephraim, B.E., B.N. Ekwueme, M. Moazzen 2006: Geothermobarometric study of rocks in northeast Obudu area, southeastern Nigeria. - Journal of Mining and Geology, 42/2, pp. 95-104. 
Ernst, W.G., J. Liu 1998: Experimental phase-equilibrium study of Al- and Ti-content of calcic amphibole in MORB-a semiquantitative thermobarometer. - American Mineralogist, 83, pp. 925-969.

Ferré, E., G. Gleizes, J.L. Bouchez, P.N. Nnabo 1995: Internal fabric and strike-slip emplacement of the Pan-African granite of the Solli Hills, northern Nigeria. - Tectonics, 14, pp. 1205-1219.

Ferré, E., G. Gleizes, C. Caby 2002: Obliquely convergent tectonics and granite emplacements in the Trans-Saharan belts of Eastern Nigeria: a Synthesis. - Precambrian Research, 114, pp. 199-214.

Ferry, J.M., F.S. Spear 1978: Experimental calibration of the partitioning of Fe and Mg between biotite and garnet. - Contributions to Mineralogy and Petrology, 66, pp. 113-117.

Fitches, W.R., A.C. Ajibade, I.G. Egbuniwe, R.W. Holt, J.B. Wright 1985: Late Proterozoic schist belts and plutonism in NW Nigeria. - Journal of the Geological Society of London, 142, pp. 319-337.

Ganguly, J., S. Saxena 1984: Mixing properties of aluminosilicate garnets: constraints from natural and experimental data, and applications to geothermobarometry. - American Mineralogist, 69, pp. 88-97.

Grant, N.K., M. Hickman, FR. Burkhotder, J.L. Powell 1972: Kibaran metamorphic belt in PanAfrican domain of West Africa. - Nature Physical Science, 238, pp. 90-91.

Grant, N.K. 1978: Structural distinction between a metasedimentary cover and underlying basement in 600 M.Y. old Pan-African domain of northwestern Nigeria, West Africa. - Bulletin of the Geological Society of America, 89, pp. 50-58.

Hackler, R.T., B.J. Wood 1984: Experimental determination of Fe and Mg exchange between garnet and olivine and estimation of Fe-Mg garnet mixing properties. - American Mineralogist, 74, pp. 994-999.

Helffrich, G., B. Wood 1989: Subregular model for multicomponent solutions. - American Mineralogist, 74, pp. 1016-1022.

Hietanen, A. 1974: Amphibole pairs, epidote mineral, chlorite and plagioclase in metamorphic rocks northern Sierra Nevada California. - American Mineralogist, 59, pp. 22-40.

Hodges, K.V., F.S. Spear 1982: Geothermometry, geobarometry and the Al2SiO5 triplepoint at Mt. Moosilauke, New Hampshire. - American Mineralogist, 67, pp. 1118-1134.

Holland, T., J. Blundy 1994: Non-ideal interactions in calcic amphiboles and their bearing on amphibole-plagioclase thermometry. - Contributions to Mineralogy and Petrology, 116, pp. 433-447.

Indares, A., J. Martignole 1985: Biotite-garnet geothermometry in the granulite facies: the influence of $\mathrm{Ti}$ and $\mathrm{Al}$ in biotite. - American Mineralogist, 70, pp. 272-278.

Johnson, M.C, M.J. Rutherford 1989: Experimental calibration of the aluminium - in hornblende geobarometer with application to Long Valley Caldera (California) volcanic rocks. - Geology, 17, pp. 837-841.

Koziol, A.M., R.C. Newton 1988: Redetermination of the anorthite breakdown reaction and improvement of the Pl-Grt-Als-Qtz geobarometer. - American Mineralogist, 73, pp. 216-223.

Kroener, A., B.N. Ekwueme, R.T. Pidgeon 2001: The oldest rocks in West Africa: SHRIMP zircon age for early Archaean migmatitic orthogneiss at Kaduna, northern Nigeria. - The Journal of Geology, 109, pp. 399-406.

Kretz, R. 1983: Symbols for rock forming minerals. - American Mineralogist, 68, pp. 227-279.

Leake, B.E. 1978: Nomenclature of amphiboles. - Mineralogical Magazine, 42, pp. 553-563.

Leake, B.E., A.R. Woolley, C.E.S. Arps, W.D. Birch, M.C. Gilbert, J.D. Grice, F.C. Hawthorne, A. Kato, H.J. Kisch, V.G. Krivovichev, K. Linthout, J. Laird, J.A. Mandarino, W.V. Maresch, E.H. Nickel, N.M.S. Rock, J.C. Schumacher, D.C. Smith, N.C.N. Stephenson, L. Ungaretti, E.J.W. Whittaker G. Youzhi 1997: Nomenclature of amphiboles: Report of the Subcommittee on Amphiboles of the International Mineralogical Association, Commission on New Minerals and Mineral Names. - American Mineralogist, 82, pp. 1019-1037.

Maboko, M.A.H. 1997: P-T condition of metamorphism in the Wami River granulite complex, central coastal Tanzania: implications for Pan-African geotectonics in the Mozambique belt of eastern Africa. - Journal of African Earth Sciences, 24, pp. 51-64. 
McCurry, P. 1971: Pan-African Orogeny in Northern Nigeria. - Geological Society of America Bulletin, 82, pp. 3251-3263.

Mullan, H.S. 1979: Structural distinction between a metasedimentary cover and an underlying basement in the 600 m.y. old Pan-African domain of northwestern Nigeria, West Africa: Discussion. - Geological Society of American Bulletin, 90, pp. 983-984.

Mvondo, H., S.W.J. den Brok, J. Mvondo Ondao 2003: Evidence for symmetric extension and exhumation of the Yaounde nappe (Pan-African fold belt, Cameroon). - Journal of African Earth Sciences, 36, pp. 215-231.

Odeyemi, I.B. 1976: Preliminary report on the field relationships of the basement complex rocks around Igarra Mid-West. - In: Kogbe, C. A. (Ed.): Geology of Nigeria. Elizabethan Press Lagos, pp. 59-63.

Odeyemi, I.B. 1977: On the Petrology of the Basement Rocks around Igarra, Bendel state, Nigeria. Unpublished PhD thesis, University of Ibadan.

Ogezi, A.E.O. 1977: Geochemistry and geochronology of basement rocks from NW Nigeria. Doctoral dissertation, University of Leeds.

Olarewaju, V.O., M.A. Rahaman 1982: Petrology and geochemistry of Older Granites from some parts of northern Nigeria. - Nigerian Journal of Mining and Geology, 18, pp. 16-28.

Oluyide, P.O. 1988: Structural trends in the Nigerian basement complex. - In: P.O. Oluyide, (compl.): Precambrian Geology of Nigeria. - Nigeria Geological Survey Publication, pp. 93-98.

Onyeagocha, A.C., B.N. Ekwueme 1982: The Pre-Pan-African structural features of north central Nigeria. - Journal of Mining and Geology, 19/2, pp. 74-77.

Onyeagocha, A.C., B.N. Ekwueme 1990: Temperature-pressure distribution pattern in metamorphosed rocks of the Nigerian Basement Complex, a preliminary analysis. - Journal of African Earth Sciences, 11, pp. 83-93.

Oversby, V.M. 1975: Lead isotopic studies from the Precambrian basement near Ibadan, southwestern Nigeria. - Earth Planetary Science Letters, 27, pp. 177-180.

Pidgeon, R.T., O. Van Breemen, M.O. Oyawoye 1976: Pan-African and earlier events in the basement complex of Nigeria. - 25th Int. Geological Congress, Sydney, Australia (Abstract Volume), $667 \mathrm{p}$.

Pigage, L.C., H.J. Greenwood 1982: Internally consistent estimates of pressure and temperature: The staurolite problem. - American Mineralogist, 282, pp. 943-969.

Powell, R., TJ.B. Holland 1988: An internally consistent thermodynamic dataset with uncertainties and correlations: 3 application to geobarometry, worked examples and computer program. Journal of Metamorphic Geology, 6/1, pp. 73-204.

Rahaman, M.A. 1973: The geology of the district around Iseyin, western state, Nigeria. - PhD thesis, University of Ibadan.

Rahaman, M.A. 1976: Review of the basement geology of southwestern Nigeria. - In: Kogbe, C. A. (Ed.): Geology of Nigeria. Elizabethan Press, Lagos. pp. 41-58.

Rahaman, A.M., E.E. Ukpong, M. Azmatullah 1981: Geology of parts of Oban massif, southeastern Nigeria. - Journal of Mining and Geology, 18/1, pp. 60-65.

Snelling, N.J. 1964: A review of age determinations from Northern Rhodesia. - Economic Geology, 59/6, pp. 961-981.

Thompson, A.B. 1976: Mineral reactions in pelitic rocks: II. Calculation of some P-T-X (Fe-Mg) phase relations. - American Journal of Science, 276, pp. 401-454.

Torquato, J.R., U.G. Cordani 1981: Brazil - Africa geological links. - Earth Science Review, 17/1 and 2, pp. $155-176$.

Toteu, S.F, R.W. Van Schmus, J. Penaye, A. Michard 2001: New U-Pb and Sm-Nd data from northcentral Cameroon and its bearing on pre-Pan-African history of central Africa. - Precambrian Research, 108, pp. 45-73.

Toteu, S.F., J. Penaye, Y.P. Djomani 2004: Geodynamic evolution of the Pan-African belt in central Africa with special reference to Cameroon. - Canadian Journal of Earth Sciences, 41, pp. 73-85. 
Tougarinov, A.I., K.G. Knorre, L.L. Shanin, L.N. Prokofieva 1968: The geochronology of some Precambrian rocks of southern West Africa. - Canadian Journal of Earth Sciences, 51, pp. 639-642.

Ukwang, E.E., B.N. Ekwueme, R.J. Horsley 2003: Petrology of granulite facies rocks in Ukwortung area of Obudu Plateau, southern Nigeria. - Global Journal of Geological Sciences, 1/2, pp. 159-168.

Umeji, A.C., M. Caen-Vachette 1984: Geochronology of Pan-African Nassarawa Eggon and MkarGboko granites, Southeast Nigeria. - Precambrian Research, 23, pp. 317-324.

Van Breemen, O., R.T. Pidgeon, P. Bowden 1977: Age and isotopic studies of some Pan-African granites from north central Nigeria. - Precambrian Research, 4, pp. 307.

Vernon, R.H. 1987: Growth and concentration of fibrous sillimanite related to heterogeneous deformation in K-feldspar-sillimanite metapelite. - Journal of Metamorphic Geology, 5, pp. 51-68.

Wright, E.P. 1971: Basement complex. - Geological Survey of Nigeria Bulletin, 32, pp. 12-47. 